\title{
STRATEGIC ASSET MANAGEMENT IN THE SOCIAL RENTED SECTOR: APPROACHES OF DUTCH AND ENGLISH HOUSING ASSOCIATIONS
}

Revised manuscript October 2003

\author{
Vincent Gruis, Nico Nieboer and Andrew Thomas
}

\author{
Vincent Gruis \\ Department of Real Estate \& Housing \\ Faculty of Architecture \\ Delft University of Technology \\ Berlageweg 1 \\ NL - 2628 CR Delft \\ $\mathrm{T}:+31-15-2783928$ \\ F: +31-15-2783411 \\ E: v.h.gruis@tudelft.nl
}

Nico Nieboer

OTB Research Institute for Housing, Urban and Mobility Studies

Delft University of Technology

Andrew Thomas

HACAS Chapman Hendy 


\section{STRATEGIC ASSET MANAGEMENT IN THE SOCIAL RENTED SECTOR: APPROACHES OF DUTCH AND ENGLISH HOUSING ASSOCIATIONS}

Summary. In England and the Netherlands, in response to changes in housing policy and the market, there is widespread enthusiasm for asset management in the social rented sector. A key issue in both countries is the development of a strategic approach towards the formulation of asset management plans. Our paper examines this issue in relation to the current practice of housing associations in both countries. Drawing on case studies in England and the Netherlands we conclude that in both countries practice varies widely between housing associations. Some of the approaches adopted by front-runners can be seen as models for other associations yet to develop a strategic approach towards asset management. Lessons can also be learnt across national boundaries, though necessarily mediated by differences between the two housing systems.

\section{Introduction}

In many countries housing systems are in transition as part of a more general trend towards privatisation and decentralisation of public services. In a number of Western European countries government financial support for social landlords has been reduced and in some countries this has meant social landlords being less bound by specific regulations and more self-reliant (e.g. Boelhouwer, 1997, 1999; Smith and Oxley, 1997). At the same time there is increasing pressure on social landlords to improve their performance in terms of 'effectiveness' and 'efficiency' (see for example Walker and van der Zon, 2000). Furthermore, despite the expanded role being claimed for housing associations in urban renewal, the role of social housing has become more focused on the management of housing stock as development activity has declined in importance in comparison with the size of the existing stock (e.g. Thomsen and van der Flier, 2002). In some cases social landlords have been faced with managing stock in areas of low or declining demand, or own stock on estates where there are complex combinations of social, technical and demand issues. This transformation of housing systems and markets has lead to a more market-oriented social housing management (e.g. Priemus et al., 1999). One component of this is that landlords in some countries, including the

Netherlands and England, have introduced the concepts of 'asset management' and 'strategic business planning'.

Asset management is concerned with an analysis of the performance of an organisation's assets in support of decisions about holding, selling and repositioning. In private sector asset management, the emphasis is on optimising financial performance. In the social rented sector, financial performance is not the primary criterion for management decisions. The key-question for social landlords is how to reach their social housing objectives efficiently (Gruis and Thomas, 2002). Hence, Larkin (2000, p. 8) defines asset management in the context of social housing as "the range of activities undertaken to ensure that the housing stock meets needs and standards now and in the future in the most efficient way". 
Strategic planning is the process of developing and maintaining a viable fit between the organisation's objectives and its recourses (Hannagan, 1992, p. 38). Although it has its origins in the private sector, this concept has also been introduced in the management of public organisations (see e.g. Bryson, 1995). Many advantages are ascribed to following a strategic approach towards business planning. For example, according to Fraser and Stupak (2002, p. 1203) "advocates of strategic planning believe the process will amplify and enhance systematic information gathering, clarification of organisational direction, establishment of priorities, quality decision making, communication and understanding of strategic intent, solid organisational responsiveness, effective performance, conscientious framework, useful application of expertise, and attention to organisational learning." In short, strategic planning is expected to contribute to an organisation's effectiveness and efficiency by following a systematic, rational and transparent planning process.

In this paper, asset management and strategic planning are considered together as 'strategic asset management' - a term that has been introduced in the Dutch social rented sector in the early 1990s. Since then, as a result of housing reforms, social landlords in the Netherlands have gained a considerable degree of administrative and financial independence. During the 1990 s the market position of the social rented sector was weakening due to the booming economy and a shift in housing preferences towards owner-occupation. These developments lead to a widespread interest in the strategic management of the social housing stock There were certain parallels in the English experience, with a shared interest in developing methods and tools for the management of the social housing stock.

\section{Recent developments in England and the Netherlands}

In England, local authorities and housing associations are under pressure to develop business-like approaches towards housing management (Walker, 1999). From 2001/02, local authorities in England began to operate under a new financial framework. The old Housing Revenue Account (HRA) was replaced by a new 'resource account' reflecting capital and depreciation. The associated introduction of business plans (DETR, 2000) is part of the process of encouraging authorities to make better use of their housing assets. As the asset management plan for housing, these business plans draw on stock condition survey data, and in the future may result in more sophisticated approaches to asset management modelling.

Housing associations operate in a parallel world. Though not affected by the same regulatory regime as local authorities, aspects of business planning have been part of the associations' operational framework for a number of years. The Housing Corporation, which until recently monitored the activities of English associations, adopted performance and 'Best Value' criteria, and this approach has been continued by the Audit Commission. In the 1980s, housing associations became the government's preferred provider of social housing, among other reasons because they were seen as more detached from government and were expected to operate more like 'real' players in the market (Walker and Van der Zon, 2000). Following the 1988 Housing Act, which exposed associations to private sector finance under a mixed funding regime, there have

effectively been no government grants to cover future maintenance costs. The importance 
of asset management has therefore been given prominence because associations must make adequate financial provision from their own resources for the future repair and maintenance of their stock (NHF, 1997). Risk management has become even more pressing in the context of 'rent convergence': the government's objective to set rents across the social sector on a common system based on relative property values and local earnings (DETR, 2000a). The effects of convergence depend on local property values and existing rent levels, but some associations will experience a real reduction in rents over the ten year implementation period. In this climate, if associations are to manage their financial affairs prudently, they need to understand the future shape of stock investment requirements. In turn this requires information on which to plan, and stock condition surveys have been undertaken by many associations over the last ten years, initially under guidance from the NFHA (1994), and more recently DETR (2000b). Some work has also been done on cost forecasting (Housing Corporation, 1999), and individual associations have developed approaches for renewal strategies, particularly associations that have to deal with low demand and unpopular estates (e.g. Larkin, 2000). Another development that stimulates the development of asset management is the process of 'large scale voluntary stock transfers' from local authorities to (new) housing associations. This privately funded sale between landlords requires a detailed assessment of the quality, market position and financial prospects of the concerning housing stock, resulting in business plans.

In the Netherlands, one of the key elements in the reinforcement of market principles in social housing has been the deregulation of housing associations' activities. Until the 1990s, Dutch housing associations operated under a strict regulatory framework and were largely dependent on government financial support. Publication of the Memorandum on "Housing in the Nineties" paved the way for greater independence. This took two forms. First, direct financial support in the shape of 'brick-and-mortar' subsidization and government loans has been abolished, leaving housing associations with the challenge to fully finance their social housing investments with capital-market loans and their own resources (consisting of reserves that had been built before the 1990s and proceedings from sales and project development of more expensive owner-occupied en rental dwellings). Second, the prescriptive regulations were replaced by the principle of retrospective accountability. Since the introduction of the Social Rented Sector Management Decree (BBSH) in 1993, housing associations operate in a system in which they are supervised on the basis of general 'fields of performance': accommodation of target groups; preservation of the quality of dwellings and their environment; consultation of tenants; securing financial continuity; and providing housing and care arrangements. Within the new regulatory framework associations became responsible for determining their own asset management policies. Consequently, much more attention is now given to the development of 'strategic' asset management (e.g. Nieboer and Gruis, 2002). Financial independence has led associations to adopt techniques for financial appraisal in support of management strategies (e.g. CFV, 2001; Van den Broeke, 1998). They have begun to develop strategic business plans, based on portfolio analysis, and are experimenting with balanced score cards and benchmarking for the measurement of performance.

\section{Aims and approach}


In the Netherlands and England, regulatory and market trends have increased interest in asset management within the social rented sector. However approaches are still at an early stage of development. Some techniques have been widely adopted, while others have as yet been applied by just a few 'front-runners'. There are still many questions about how asset management techniques should be adopted to fit the context of social housing (Gruis and Thomas, 2002). A key issue in both countries is the development of a strategic approach towards the formulation of investment strategies (e.g. Larkin, 2000; Nieboer and Gruis, 2002). Landlords need to develop comprehensive asset management strategies that addresses questions about what parts of the stock should be improved, maintained, sold or demolished. Asset management strategies need to respond proactively to housing market developments to prevent the occurrence of estates with social problems

and high levels of voids. Systematic approaches are needed to enable transparent and rational decision-making.

In this paper we evaluate and compare the current practice of Dutch and English housing associations. The choice of Dutch associations is driven by their effective monopoly of social housing provision, owning over $99 \%$ of the social housing stock in the Netherlands. As private institutions with public objectives the obvious comparison is with English housing associations, rather than local authorities, though there are clear points of reference to local authority housing with the distinction between sectors being eroded through stock transfer and arms length management companies.

In our evaluation we use a theoretical evaluation framework in which keycharacteristics of 'strategic asset management' are described on the basis of literature on strategic business planning. Then we describe the function of Dutch and English housing associations within their national housing systems and markets, and we set their asset management practice against the characteristics of strategic asset management. Finally we reflect on the similarities and differences between the asset management practice of associations in the two countries and discuss possible explanations for the differences.

\section{Strategic asset management in the social rented sector}

Strategic asset management can be typified on the basis of interrelated characteristics that can be found in literature on strategic business planning. These business planning characteristics form the basis of our evaluation framework and can be summarised as market oriented, systematic, comprehensive and proactive. Below we reflect on these characteristics and their potential benefits for social landlords (for further discussion see e.g. Van den Broeke, 1998; Larkin, 2000; Gruis and Nieboer, 2001; Nieboer and Gruis, 2002):

\section{Market-oriented}

Asset management in the social rented sector is concerned with fulfilling a housing demand by offering a housing supply and in that sense it is market-oriented by definition. However, social housing has traditionally been provided through 'bureaucratic' mechanisms (government regulation and subsidies) and not by institutions who actively seek to improve the 'fit' of their organisation and products to their environment, which is 
a central feature of strategic planning. In general, literature on strategic planning emphasises the need of an analysis of a companies' own strengths, weaknesses in relation to the opportunities and threats in their environment in support of strategy formulation (e.g. Aaker, 1998; Kotler, 1997; Bryson, 1995). In the private sector, strategies are based on an analysis of the market position of the products, market prospects and - in general opportunities to earn money. In the 'classic' portfolio analysis, designed by the Boston Consultancy Group, cash-performance is crucial in the analysis of business units (see Ansoff, 1984). In analogy with commercial practice, a market-oriented landlord can be expected to place more emphasis on analysing market demand and opportunities. Important decision-making factors in strategy formulation will be current lettability, future market expectations, financial return and opportunities for sale. A wide range of strategies will be considered and applied: diversification of the price and quality of dwellings within the portfolio according to housing demand will be a central theme in asset management.

Of course, the specific characteristics of social landlords do not allow them to behave exactly like commercial enterprises. They are for example restricted to offering (social) housing and (hence) financial return is not their primary objective. Nevertheless, within these boundaries, increased market orientation can have benefits for social landlords as well. Market orientation can help social landlords to realise a portfolio which is effective (in meeting housing demand and tenants' preferences) and economically efficient (using 'cash cows' to finance the core social housing stock). In short, we use the term 'market-orientated landlord' in contrast to a task-oriented or responsive landlord whose focus is mainly on fulfilling 'traditional' social housing tasks: the letting of decent, affordable dwellings. (This distinction between task-oriented and market-oriented is comparable to the distinction made by Miles and Snow (1978) between 'Defenders' and 'Prospectors'. It is also interesting to compare this concept with Kemeny's (1995, p. 1116) discussion on market conformity.) The occurrence of market orientation can be reflected in the various activities of social landlords' asset management: the rent(increases) will be related to the quality and market position; the allocations, maintenance and renewal activities will take market demand and tenants' preferences into account and the landlords will have an active sale policy to generate financial income and meet housing preferences.

\section{Systematic}

Many books on strategic business planning suggest the use of systematic planning procedures and rational frameworks for decision-making. Thus, within strategic asset management, a landlord will put effort into rational and transparent decision-making. The process of formulating asset management strategies will be well-structured. Decisionmaking factors will be clearly marked and the way in which decisions are reached will be reported. Asset management decisions have a large influence on the quality, affordability and availability of dwellings, being the key-objectives of social housing everywhere. This impact on social housing objectives places a demand on the quality of the decisionmaking process. Stakeholders of social landlords may expect a 'justifiable' policy, which is supported by rational arguments as part of a transparent decision-making process. In fact, it can be argued that social landlords should strive towards such a transparent policy 
as part of their social objectives. The occurrence of a systematic approach towards asset management can be reflected in the application of decision-making frameworks comparable, for example, with private sector portfolio analyses - and structured processes - comparable for example with strategic business planning as described by Kotler (1997, p. 80), Aaker (1998, p. 19) and Bryson (1995, pp. 22-37).

\section{Comprehensive}

A major characteristic of strategic business planning is that it deals with the objectives of the organisation as a whole, at top management-level. In general, models for strategic planning include the formulation of a mission statement and business goals to guide the development and activities of an organisation. Products or 'business units' are analysed and compared with each other in the light of this mission. As stated at the beginning of this section, asset management concerns only a part of a social landlords' activities. Nevertheless, the characteristic of 'comprehensiveness' can be applied to the specific area of asset management. Comprehensive asset management will focus not only on individual dwellings or estates, but will also reflect on the composition of the stock as a whole. Furthermore, different aspects of stock management will be considered. For example, technical and social activities, long-term and short-term objectives, and activities at a strategic and operational level. A landlord operating in only a responsive way will focus for example on problem estates, failing to formulate objectives for the development of the whole housing stock and will not consider the (lack of) synthesis of different parts of the total management approach. A comprehensive (portfolio) approach helps social landlords to determine which part of the stock should be given priority for investment and intensive management. Furthermore, reflection on the desired growth direction of the portfolio as a whole, in relation to housing needs, allows them to put decisions about individual estates in a wider perspective.

\section{Proactive}

The final key-characteristic of strategic asset management that we consider in our evaluation framework is the occurrence of a pro-active approach. Books on strategic planning are very clear on the fact that strategic behaviour is not about taking a passive attitude towards developments in the company's environment. For example Ansoff (1984, p. xv) states strategic planning "is a systematic procedure for management which anticipates the challenge and prepares its responses in advance, based on examination of novel alternatives". Strategic planning can be set between 'long-range planning', which is based on (sometimes inadequate) extrapolative forecasts, and 'strategic management', which suggests real-time strategic response to the dynamic environment (e.g. Ansoff, 1984, Aaker, 1998). It is interesting to note that, from a historic perspective, strategic management has evolved from strategic planning, because the 'planning cycle' used in strategic planning is assumed to be "inadequate to deal with the rapid rate of change that can occur in a firm's external environment" (Aaker, 1998, p. 11). However, we argue that for management of the housing stock, real-time strategic management is not realistic due to the inflexible nature of this product. Nevertheless, we recognise pro-activeness as a key-characteristic of both strategic planning and strategic management. Translated to 
asset management in the social rented sector, a proactive approach implies that landlords will actively identify problems and opportunities stemming from developments in the housing market, housing policy and market position. Furthermore, they will anticipate these developments with asset management strategies instead of reacting to them after potential problems have become reality (for example, initiating renewal before a neighbourhood begins to deteriorate).

In summary, we use the term 'strategic' for landlords who follow a market-oriented, systematic, comprehensive and proactive approach towards asset management. In Table 1, we have summarised possible (qualitative) 'indicators' of the occurrence of these characteristics. In the following sections we employ these characteristics of strategic asset management when describing the practices in both countries.

Table 1: Characteristics and 'indicators' of strategic asset management

\begin{tabular}{ll}
\hline $\begin{array}{l}\text { Characteristic of strategic } \\
\text { asset management }\end{array}$ & 'Indicator' of occurrence \\
\hline Market-oriented & $\begin{array}{l}\text { Rents, allocations, sales, maintenance and renewal are related to tenants' } \\
\text { preferences, market demand and financial return/opportunities. }\end{array}$ \\
Fystematic & $\begin{array}{l}\text { Frameworks for decision-making and (structured) planning processes are } \\
\text { applied. }\end{array}$ \\
Gomprehensive & $\begin{array}{l}\text { Goals are formulated for the development of the entire housing stock and } \\
\text { individual estates are analysed in relation to each other. }\end{array}$ \\
Proactive & Investments and other activities anticipate threats and opportunities.
\end{tabular}

\section{Methodology}

The description of Dutch practice is based on a literature review, and on interviews held in winter 2002 with eleven housing associations which are supposed front-runners in the area of asset management (see Nieboer \& Gruis, 2002; Nieboer, 2003). The description of English housing associations is based mainly on the case studies conducted by Larkin (2000). Although both studies have been conducted by different researchers, the topics are very similar. Both studies investigate the asset management practice of housing associations and highlight good practice. Both studies have selected housing associations that have taken steps to develop a strategic asset management (Nieboer, 2003, p. 9; Larkin, 2000, p. 13). Therefore, they provide a good basis for our comparison, but there is some imbalance in the availability of information - discussion of English practice is somewhat hampered due to the lack of systematic information. Furthermore, our analysis must be viewed within the context of the following (methodological) restrictions:

Because of the large variety in institutional, political, economic and historic conditions between countries, comparative housing research often faces the problem of what is actually being compared. According to, for example, Smith (1997) this makes the use of clear definitions absolutely necessary as a basis for analysis. This problem is prominent in our research, in which we try to determine if landlords comply to the abstract notion of 'strategic behaviour'. Although we define the underlying characteristics of such an approach, these (necessarily) remain rather abstract as well. Furthermore, in practice mixed forms exist with some landlords being comprehensive and systematic but not 
market-oriented. Hence it is not possible to classify landlords rigidly into 'strategic' and 'non-strategic';

- The historic context makes it difficult to make conclusive statements at this moment. As stated in the introduction, asset management is still in a development stage in both countries. Organisations need a lot of time to adapt to their new situation. Being aware of the early stage of development, we have supported our analysis by examples from front-runners;

- $\quad$ It must be noted that our evaluation framework is rather prescriptive. Based on existing theories, and given the current interest in strategic asset management in England and the Netherlands, we have stressed the potential benefits of following a strategic approach towards asset management. The strategic planning approach is, however, not free of criticism (see e.g. Mintzberg, 1994 - compare with the discussion on rational and incremental approaches). Furthermore, application of some of the characteristics in the social rented sector could 'backfire'. This counts in particular for market orientation: if this leads to market conformity in a sense that social housing tasks are forgotten and profit-making becomes the leading motivation, social landlords will loose their position as effective contributors to the fulfilment of social housing needs. But it is not the objective of this article to debate the relevance of strategic planning and our model is primarily intended to facilitate comparison between practice of Dutch and English housing associations.

\section{Asset management in Dutch housing associations}

Housing associations are by far the largest providers of social housing in the Netherlands. In 2001 there were 620 associations, owning more than $99 \%$ of the social housing stock (CFV, 2002). They are not-for-profit organisations obliged to operate in the interest of housing, in particular by providing decent, affordable housing to lower-income households. During the 1990s the average size of the housing associations' stock grew substantially due to mergers between associations (see Priemus, 2001). In 2001 the average number of dwellings per association was 3,800 (CFV, 2002). When set within an international context, their stock can be characterised by its relatively large share of the total housing stock (35\%), the diversity of dwellings (type, price) and the variety of tenants, who are not only low-income households (e.g. Van der Heijden, 2002). Generally speaking, the market position of the social rented stock is good. Although in some regions lettability has been under threat in the 1990s, pressure on the social housing market has increased in recent years, resulting in longer waiting periods throughout the Netherlands. Dutch associations are managed by a professional organisation and board. Nearly all associations have a sound financial position, certainly when taking into account the solid guarantee structure in the Dutch social rented sector (see below). Of course, in this short sketch we only paint the general picture. Differences exist between the associations' housing stock quality, size, financial resources and organisation.

In the nineties, after decades of strong central government regulation, Dutch housing policy changed towards the reinforcement of market principles in social housing. As part of this policy housing associations have gained much more administrative 
freedom. Government regulation of associations activities has been replaced by the principle of retrospective accountability on the basis of general 'fields of performance' (see introduction). These legal responsibilities are formulated in the Social Rented Sector Management Decree (BBSH). This decree stipulates that all the activities of housing associations have to be in the interest of housing. Housing associations must give priority to accommodating households with a weak position in the housing market (mainly lowerincome households), but they are also allowed to provide dwellings for others. As a consequence, Dutch housing associations are often typified as 'hybrid' organisations, which carry out public tasks, but are independent, private organisations, having market driven objectives as well (Priemus, 2001, pp. 247-249). The performance of the housing associations is monitored by the Housing Ministry, except for the financial assessments of the associations, which are conducted by the Central Housing Fund (CFV).

The current legislation leaves associations a lot of room to determine their own asset management policy. Associations are primarily responsible for their own maintenance, renewal and sale policy. Allocation policies are often determined in cooperation with the municipalities. Only rents are still heavily regulated by central government.

In parallel with deregulation, direct financial support for housing associations has been completely withdrawn (e.g. Boelhouwer, 1997). However, indirect financial support still exists through individual housing grants. Furthermore associations' loans can be guaranteed by the Social Housing Guarantee Fund (WSW), which is funded by fees from the associations and backed-up by the government. Associations that are no longer able to secure their financial viability can apply for financial support from the Central Housing Fund, which is also funded by associations' fees (e.g. Priemus, 1996).

The new policy context has set considerable challenges for the asset management of Dutch social landlords. Being transformed from operational, task-oriented organisations towards 'social entrepreneurs', they have to operate in a more strategic way. But to what extent is this reflected in their asset management practice?

\section{Market-orientation}

Increased market-orientation is reflected in different aspects of the associations' asset management:

Rent policy: in response to the freedom they gained during the 1990s with the introduction of the so-called rent sum approach (e.g. Boelhouwer et al., 1997), associations have developed systems to differentiate their rents on the basis of normative price-quality ratio's and analyses of the market position of dwellings. The market orientation of the housing associations' rent policy is reflected in the results of surveys conducted by the research institutes OTB in 1996 (Kersloot,1999) and RIGO in 1999 (Marsman and Smit, 1999). In the OTB survey, the most frequent reason given for rent increases concerned the pricequality rate of the dwellings; the second reason was concerned with the affordability and/or price-quality rate of other dwellings. In the RIGO survey, the most frequent reasons concerned the local housing market and the financial position of the associations. Since July 2002, however, new national rent regulations are in force which substantially confine the policy freedom of 
housing associations enjoyed in the 1990s. The former State Secretary of Housing implemented a mid-term rent policy for the period until 2005 which links maximum rent increases to inflation, and the maximum eligible rent according to the Housing Valuation System. Furthermore, the government has set a maximum rent increase for the total housing association stock of inflation plus $0.4 \%$.

- $\quad$ Allocation policy: throughout the Netherlands 'market-oriented' advert models have replaced the distribution model for allocation of dwellings (e.g. Kullberg, 2002);

Stock quality policy: housing associations have begun to differentiate their policies on quality according to the market position of dwellings, target groups' preferences and incomes. Nevertheless, Straub (2002, p.374) states that "a clear coupling between the strategic stock policy and the technical management with respect to planned maintenance is still lacking in many cases".

- $\quad$ Sale policy: sales have become a key-aspect of associations' asset policies. The number of dwellings sold grew from 2,000 in 1990 to over 20,000 a year in the late 1990s. According to the Ministry of Housing "mainly the more expensive dwellings are being sold and the cheaper stock seems to be maintained as much as possible for housing the target group" (MVROM, 2000b, p.11). Survey results show that important reasons for sale are "the use of proceedings from sale to acquire new dwellings for target group" and the fact that "dwellings became too expensive for target group" (Kersloot, 1999, p. 88).

- $\quad$ Financial return has gained in importance for housing associations. This is reflected, for example, in the development of a benchmark for financial return on the housing associations' stock: the so-called AEDEX (see e.g. Priemus, 2003). However, financial return is still far from conclusive in their decisions, since housing associations accept large financial losses on investments in new and existing dwellings (e.g. CFV, 2002).

Case 1. Differentiation of stock quality

Housing association De Combinatie in Rotterdam works with four categories to differentiate the technical quality of their housing stock in respect to, for example, the facilities in the kitchen and bathroom, insulation and safety provisions: Champions League (highest quality), Premier League, Second Division (minimum quality) and All Stars (for special types of housing, e.g. homes for the elderly, student rooms or dwellings for groups) (see Boor et al., 2002). Some examples of differences in technical quality are mentioned below.

\begin{tabular}{lllll}
\hline \multicolumn{1}{c}{ Category: } & $\begin{array}{l}\text { Champions } \\
\text { League }\end{array}$ & Premier League & Second Division & All Stars \\
\hline $\begin{array}{l}\text { Length of kitchen } \\
\text { sink (in metres) }\end{array}$ & at least 2.10 & $1.80 \mathrm{~m}$ & no minimum & $1.80 \mathrm{~m}$ \\
$\begin{array}{l}\text { Number of cupboards } \\
\text { in kitchen }\end{array}$ & at least 3 & 2 at least & no minimum & 2 at least \\
$\begin{array}{l}\text { At least one toilet in } \\
\text { room separate from } \\
\text { bathroom }\end{array}$ & required & not required & not required & not required \\
\end{tabular}




\begin{tabular}{lllll} 
Washbasin / sink & at least 2 & at least 1 & not required & $\begin{array}{l}\text { depends on type of } \\
\text { dwelling }\end{array}$ \\
Double glass & $\begin{array}{l}\text { double glass in } \\
\text { living, kitchen and } \\
\text { all bedrooms }\end{array}$ & $\begin{array}{l}\text { double glass in } \\
\text { living and kitchen }\end{array}$ & not required & \\
\hline
\end{tabular}

Case 2. 'Client's choice' programme Woonbron-Maasoevers

Housing association Woonbron-Maasoevers in Rotterdam is experimenting with a programme in which, for a part of the housing stock, tenants are given the choice of five tenure options:

- $\quad$ Normal rent contract;

- $\quad$ Fixed rent contract for 5 or 10 years;

- $\quad$ Fixed rent-increase contract for 5 or 10 years;

- $\quad$ Purchase, with a discount on the market value and a sale-back guarantee with a fiftyfifty division of growth (or decrease) in value between the housing association and the 'tenant';

- Outright purchase, under the condition that the landlord has the right to buy the dwelling back against market value when the 'tenant' sells the dwelling.

Other associations have followed this experiment as well (e.g. Saenwonen in Zaandam and Woonstede in Ede) and many associations have adopted certain parts of the approach.

\section{Systematic}

Since the early 1990s much attention has been given to the development of methods and instruments to inform asset management in a more systematic and business-like manner (for an overview see Nieboer and Gruis, 2001). Some associations have adopted approaches based on 'commercial' portfolio analyses, in which characteristics of the dwellings (e.g. market position, quality, price, financial return) are translated into general strategies such as 'milk', 'divest', 'maintain' or 'grow' (e.g. van der Flier and Gruis, 2002). However, our interviews with associations indicate that few actually follow a systematic approach in developing their asset management strategies.

Case 3. Systematic strategy selection Delftwonen

Dutch housing association Delftwonen uses a decision tree, based on a 'classic' portfolio analysis, in which strategies are based on assessments of future market perspective, current lettability and economic opportunity costs (measured as the ratio between the Net Present Value under continued social rent and the market value):

\begin{tabular}{lccl}
\hline $\begin{array}{l}\text { Market } \\
\text { perspective }\end{array}$ & Lettability & Economic opportunity costs & General strategy \\
& & Low & Grow \\
& Good & High & Milk \\
No risk & & Low & Reinforce \\
& Bad & High & Improve marketing, retreat
\end{tabular}




\begin{tabular}{|c|c|c|c|}
\hline \multirow{4}{*}{ Risk } & \multirow{2}{*}{ Good } & Low & Maintain \\
\hline & & High & Maintain (for now) \\
\hline & \multirow{2}{*}{$\mathrm{Bad}$} & Low & Reinforce, retreat \\
\hline & & High & Improve marketing, retreat \\
\hline
\end{tabular}

Source: Delftwonen (2002).

In brief, the general strategies in this decision tree are as follows:

- Improve marketing: improve lettability, but without increasing economic loss, for example by changing allocation criteria and being more active in marketing. If investments in quality are deemed necessary, they should be financed by the sale of dwellings in the same productgroup;

- Grow: develop more of these products and cherish the ones in the current stock;

- Maintain: continue current policy for these products;

- Milk: improve financial return by increasing rents;

- Retreat: sell or demolish.

\section{Comprehensive}

Many associations speak of 'portfolio management', but few actually formulate explicit, measurable goals for the development of their housing stock. Neither do they follow a top-down approach in formulating their investment strategies (such as in example above). Our material is not conclusive about the degree to which long-term and short-term policies and technical and social management are attuned to each other.

Case 4. Targets for development of housing stock Delftwonen

Delftwonen has formulated quantitative goals for the development and performance of their housing stock, based on an analysis local housing market developments and normative judgements. The sum of the outcomes of strategies at estate level (see example 3) are set against these targets by means of ex-ante evaluation:

\begin{tabular}{lll}
\hline Aspect & Goal \\
\hline Investments & - & Replacement of 330 cheap flats with lift; \\
& - & Replacement of 670 cheap flats without lift; \\
& - & Upgrading of 660 flats; \\
& - & Adjustment of 660 homes for the elderly; \\
& - & Adjustment of 250 single-family dwellings ; \\
& - & Upgrading of 250 single-family dwellings for families.
\end{tabular}

Price, housing Minimally:

of low-income - all dwellings for younger households have to be affordable with individual households housing allowance;

- $\quad 80 \%$ of the dwellings for the elderly affordable with housing allowance;

- $50 \%$ of the other dwellings affordable with housing allowance.

Special target Provide in 50\% of the local housing need of special groups [like handicapped people]. 
groups

Quality No dwelling with rating 'poor'. Desired differentiation of housing stock's quality:

- $30 \%$ 'basic';

- $\quad 60 \%$ 'standard';

- $10 \%$ 'luxurious'.

Sale Sale of maximally 3,000 homes.

Source: Delftwonen (2002)

\section{Proactive}

Renewal of large parts of the social housing stock to prevent future social and lettability problems is a big issue in the Netherlands, but the statistics show that this has not yet taken place on a large scale (van der Flier and Thomsen, 1998; Wassenberg et al., 2002). This can be explained to a large extent by 'external factors', such as complicated building legislation and the lack of opportunities for moving existing tenants due to the general housing shortage. Perhaps, also, there is an absence of proactive behaviour by housing associations, who lack a sense of urgency when problems are not clearly apparent.

\section{In summary}

Dutch associations have a large degree of administrative and financial independence, operate a stock with a fairly wide variety of dwellings and tenants and are managed as professional organisation. Thus we would expect associations in the Netherlands to follow a strategic approach towards asset management. In reality, strategic asset management only plays a limited role, though with exceptions: some front-runners do meet all our criteria of strategic management. Associations have certainly increased their market-orientation but it cannot be said that the majority operate in a systematic, comprehensive and proactive manner. This can be explained partly by the relatively short period of independence since the 1990s following a long tradition as semi-public taskoriented organisations. The situation can be expected to change in the future. Housing associations consider strategic asset management to be one of the most important policy issues they face (see Primavera and van de Wijgert, 2002).

\section{Asset management in English housing associations}

Two types of social landlord exist in England. Local authorities operate the largest part of the social housing stock, representing 13\% of the total stock in 2001 (Newey, 2002). The rest is operated by housing associations. Local authorities can be typified as public housing companies. Housing associations can be regarded as private institutions, but being Registered Social Landlords they have public objectives and operate under specific regulations. Since the mid-eighties housing associations have become the preferred providers of new social housing and their share in the housing stock has increased from $2 \%$ in 1979 to $7 \%$ in 2001 (Newey, 2002). There are just over 2,000 housing associations registered with the Housing Corporation, each owning an average of just over 700 dwellings. There are great differences among them. There is "a wide range of quite different organisations, varying from ancient almshouses trusts and Victorian charitable 
foundations to self-build co-ops and former local authority housing departments" (Malpass, 2001, p.227). The largest 7\% of associations (owning over 2,500 dwellings) account for $78 \%$ of all dwellings in the sector, with these associations managing an average of about 8,000 dwellings (Gruis and Thomas, 2002). As in the Netherlands, frequent mergers between associations have also become a phenomenon in England (e.g. Kiddle, 2002). However, compared to the Netherlands, the English social rented sector is much more focused on housing low-income households (e.g. van der Heijden, 2002, p.334). In general the market-position of their dwellings is good. Case studies by Larkin (2000, p.13) show that "the majority of housing association's stock is in good condition and well located...However, it is also clear from the case studies that a substantial proportion of the stock of housing associations presents asset management issues which require a more fundamental appraisal of the options available". English associations have a board of volunteers, but are "run as businesses" (Newey, 2002, p.10). According to Walker (2001, p.684) " a number of studies have noted the changing and more influential role of housing associations' chief executives (Pollit et al., 1998; Riseborough, 1997) over their board as their management and organisation becomes more complex (Mullins, 1998)".

English associations are not directly controlled by central government, but a registered housing association operates under the (centralised) regulation of the Housing Corporation. Until recently, the Housing Corporation monitors the financial and management performance of housing associations, allocated public money and promoted the development of associations (Boelhouwer, 1997), but now the Audit Commission has taken on the inspection of housing associations.

With the 1988 Housing Act public finance was altered through a system of mixed finance, and operational risks from them on were transferred to individual associations. However, associations have not become financially independent, since substantial public development funding has remained (e.g. Walker, 1999). The Housing Corporation still funds investment in new building and renovation through an Approved Development Programme (ADP), though this is destined to be replaced by allocations through new affordable housing programmes as single regional pots under the control of Regional Boards.

Rents charged by associations are to a large extent subject to central control. Allocation policy is determined by individual associations, but must conform to Housing Corporation requirements and may be subject to agreements with local authorities on general criteria and specific local lettings plans (Gruis and Thomas, 2002). Maintenance is primarily the responsibility of the associations, but the Housing Green Paper 2000 announced the introduction of "a decency standard to which all social housing has to comply by 2010" (Newey, 2002, p.13). The government's decency standard is highly prescriptive, and places an investment obligation on housing associations as they simultaneously face the implications of rent convergence. However, the reporting regime associated with decent homes may have refocused attention on asset management, while the baseline decency standard does not preclude higher aspirational standards, and therefore leaves open decisions about discretionary areas of investment which strategic asset management is designed to inform.

As stated in the introduction, English associations are under pressure to develop their asset management. Below we analyse if and how this is reflected in current practice, 
drawing on available material on English housing associations (Larkin, 2000; William Sutton Trust, 2000; Newey, 2002):

\section{Market-orientation}

Although English associations are under pressure to operate in a more business-like manner, there is little evidence that they have (already) adopted a market-orientated approach within in the specific area of their asset management. According to Larkin (2000, p.5) "in general, the assessment is that associations are now only coming to focus on the performance, location and viability of their existing stock". Following the Dutch experience, choice-based letting mechanisms have also been introduced in England, but these are not yet widely applied (e.g Brown, 2001). Case studies by Larkin (2000) show little evidence of strategic differentiation of the portfolio or variation of maintenance according to the market position of dwellings and household preferences. According to Larkin (2000, p. 37) "given the size of the RSL sector, and the range of asset challenges it faces, the rate of sales is relatively low". "To date, and with some notable exceptions, asset management has largely been based around the assumption that the existing stock will be retained and receive investment to meet contemporary standards" (Larkin, 2000, p.8).

\section{Systematic}

Practice varies, with case studies by Larkin (2000), William Sutton Trust (2000) and Newey (2002) showing that some associations make systematic assessment of their whole housing stock and then categorise for the purpose of asset management. They "have sought to develop a reasonably comprehensive policy framework and set of decision-making models and tools; others [most] have adopted strategies which address key asset challenges in a fragmented way, without an overall policy framework" (Larkin, 2000, p.17). Practice of systematic option appraisal and strategy selection is at an early stage of development. Some examples of efforts to systematise the deliberation between social and financial outcomes can be found in Larkin (2000, pp. 31-32), William Sutton Trust (2000, pp.58-59) and Gruis and Thomas (2002). The main problem that has been encountered in all these approaches (and Dutch experiences as well) is that social return is hard to measure and even harder to set objectively against financial return (see also Gruis and Thomas, 2002). Therefore, while a fully systematic option appraisal in the social rented sector does not seem feasible, there is much to gain from the trends seen in current practice.

\section{Case 5. Asset management process William Sutton Trust}

The case description of the William Sutton Trust (2000) provides an example of a well-structured approach towards the strategic decision-making of a large association (15,700 homes) with a geographically spread housing stock. The process model that the Trust has devised with the assistance of HACAS Chapman Hendy is in three parts:

- Estate prioritisation: based on a questionnaire completed by Trust employees working at area or estate level, all the estates were evaluated against a "sustainability index" and estates "at risk" were identified; 
- Estate assessment: the estates that had been selected in the previous stage were assessed on the basis of more detailed criteria and management strategies were developed for each estate;

- Option appraisal: the options that had been determined in stage 2 were evaluated on the basis of financial costs and benefits and 'social' benefits in the form of the expected impact of measures in relation indicators used in the sustainability index (see William Sutton Trust, 2000 for a full description).

\section{Comprehensive}

The English case studies show little evidence of the formulation of goals for the performance and development of the whole housing stock. "Some associations have developed systematic approaches to categorising their stock for asset management purposes, and then attaching strategies to particular categories" (see also the case of the William Sutton Trust, 2000). "Others [most] have adopted more pragmatic approaches, usually focussing on particular elements of their stock which are proving problematic" (Larkin 2000, p.5).

Case 6. $\quad$ Estate categorisation Bradford and Northern

Bradford and Northern have analysed their entire stock and placed the properties in one of three categories:

- 'Core stock', which displays some or all of the following characteristics: good location, context and environment; healthy demand; low turnover; low number of voids; low rent loss; generates surpluses; exhibits a variety of property conditions. These properties are maintained and modernised with priorities identified through the estate management plans;

- 'Redundant stock', which has some or all of the following characteristics: poor location, context and environment; no market envisaged; no longer meets housing need; low or no demand; high level of voids; high rent loss; high reactive maintenance spend; more likely to need rehabilitation; does not generate a surplus. These properties will be disposed of (presumably by sale or demolition), although some mothballing of properties where a comprehensive neighbourhood regeneration strategy is in place or envisaged. They are maintained to minimum legal standard where tenanted;

- 'Maintained stock', which falls in neither of the above categories and requires more research until a firm view can be taken. They are maintained while marketing plans, further analysis and market monitoring are conducted to determine future directions (Larkin, 2000, p.17).

\section{Proactive}

We have little data to support statements about the proactive behaviour of English associations. In general the level of renewal and sale of the existing stock of housing association have been stated to be low. According to Walker and Smith (1999, p.743) "the combination of development cost pressures, greater risk and higher maintenance charges has meant that the rehabilitation programme through housing associations has collapsed, [although] more so in Wales than in England". According to Larkin (2000) and Newey (2002) associations have yet to develop a more proactive approach towards their asset management. Case 6 (above) gives an example of proactive behaviour in a sense that redundant stock is identified and disposed of, unless comprehensive renewal actions are envisaged. This 'passive' approach is reflected in the other case studies that have 
been conducted by Larkin as well. However, while examples of proactive renewal strategies are not in the literature, private sector renewal policy in England most certainly involves housing associations as landlords, and they will be looking at the performance of their stock in the context of the strategic role local authorities have in this regard, if not because of their own commercial interests.

\section{In summary}

English associations are characterised by a larger degree of detailed central regulation compared with Dutch associations. They operate mainly in the interest of low-income households. Their housing stock is managed for this purpose and with notable exceptions is in generally a good market position. However, like the Dutch experience, English associations are financially independent of government other than for the funding of new development, and therefore have a strong incentive to adopt strategic approaches to asset management. While there is little evidence in the literature that English associations in general have adopted a strategic approach, serious efforts have been made to develop a more systematic and comprehensive view of asset management. As in the Netherlands, things are likely to develop further in the future in England as well. There is evidence of this in recent attention given to 'strategic' asset management among social landlords in Britain (e.g. Larkin, 2000; Newey, 2002; Brown et al., 2002; William Sutton Trust, 2000), and the specific challenges posed on their asset management by the latest Housing Green Paper 2000 (e.g. Newey, 2002). Further stimulation in the direction of strategic asset management, may come from 'New Public Management' reforms which place pressure on English associations to develop a more business-like approach, reflected for example in increased competitive behaviour; private sector management practices; more emphasis on economy; growth in hands-on top management; and the use of more explicit and measurable standards of performance (Walker, 2001). Crucially, however, the impetus will come from the inherited business plans of large scale voluntary transfer associations and the option appraisal techniques central to all government assumptions about stock reinvestment.

\section{Comparison between Dutch and English associations}

Compared with Dutch housing associations, English associations have rather less freedom to make their own asset management decisions. While associations in the Netherlands are responsible for their own investment policy, development and major reinvestment by English associations are regulated by central subsidies and programmes. While the sale of dwellings has become an important policy option for Dutch asset management, English associations have limited disposal options, and are certainly not actively encouraged to promote home ownership by selling off their stock (Gruis and Thomas, 2002). In general, English associations seem to be focused much more strongly than their Dutch counterparts on providing decent, affordable dwellings, supported by social services, for those most in need. To illustrate this, in England there is ongoing debate about whether social landlords are primarily (or should be) providers of social 
services, rather than property managers (e.g. Walker and Smith, 1999), while in the Netherlands property management is undisputed as the key activity of associations.

However, the differences should not be exaggerated. Associations in both countries have some freedom on allocations, are highly constrained on rents and have financial and administrative responsibility for the maintenance of their stock. In both countries, associations are becoming larger organisations due to mergers, and in England due to stock transfers as well. In general, associations in both countries have been under pressure to adopt more business-like approaches to various aspects of their management. But, unlike the Netherlands, this is not accompanied by reduced central regulation in England, and in Wales the opposite is true (Walker and Smith, 1999). Thus, although we can expect to find a growing strategic behaviour in asset management in both countries, English approaches seem likely to be much more confined in respect to their policy options: extensive sales and allocations and improvements targeted at middle and higherincome households (in particular) are much less likely to be considered. On the other hand, their limited options for manoeuvre could be a better environment for developing systematic and comprehensive approaches. The challenge stemming from the Housing Green Paper 2000 to restrict rents while raising the quality might stimulate English associations to develop a more dynamic approach and sell more of their stock (see also Newey, 2002). And the continued focus on affordable home ownership, both in England and Wales, may expand tenures like shared ownership, combining with right to buy, right to acquire, and the proposed equity renting schemes to both expand asset management options and dilute the delivery of conventional rented housing solutions.

In general, the Dutch associations seem to be slightly ahead of their English counterparts in the development of strategic asset management. This could be explained by various factors. We mention three possible explanations:

- The regulatory regime: as stated above, Dutch housing associations have more leeway in following their own asset management policy and also have a relatively large degree of financial independence. This enlarges the need to develop a more 'professional' asset management within the organisations. In this context it is also interesting to mention that, on the basis of Kemeny's (1995) classification, the Dutch rental system can be classified as a 'unitary rental market' within which the social landlords are encouraged to compete with profit-rental housing. The English system, on the other hand, bears more the characteristics of a 'dualist rental system' in which the social rented sector is hived of from the market into a 'command-economy sector'. A more specific analysis on the relationship between the type of rental system and the type of asset management (Gruis, Nieboer and Brown, 2003) indicated that there probably (and logically) is a relationship between the rental system and the occurrence of market-orientation among social landlords. However, such a relationship could not be found for the other characteristics of strategic asset management.

- The historic context: the stimulation of the administrative and financial independence of Dutch housing associations has been announced in the late eighties. Since then, the importance of strategic asset management has received much attention in the social rented sector in the Netherlands. This may have given them a 'head-start';

- The characteristics of the organisations: on average, Dutch housing associations are much larger than their English counterparts. Furthermore, where English housing 
associations consist of a variety of very different organisations (see Malpass, 2001), Dutch housing associations are generally managed by professionals. These organisational characteristics provide a much more fertile soil for the development of strategic asset management. This explanation is supported by the fact that many of the 'good practice' examples from England stem from the larger associations, with a geographically spread stock.

\section{Conclusion}

In England and the Netherlands there is widespread interest in asset management in the social rented sector. As a result of developments in housing policy and changes in housing markets, social landlords need to develop a more 'strategic' approach towards the management of their housing stock. In this paper we have made a preliminary assessment of the approaches by housing associations in both countries. We have defined strategic asset management on the basis of the following characteristics: market-oriented, systematic, comprehensive and proactive behaviour. Our evidence shows that, with the exception of some front-runners, strategic asset management that bears all of these characteristics is rare among associations in both countries. In general, the Dutch associations seem to be slightly ahead of their English counterparts, which seems logical judging from their wider role in the housing market, the less restrictive regime under which they operate and the relatively large degree of financial independence of Dutch associations.

\section{Implications for practice}

Given that asset management is in an early stage of development in both countries, are there lessons which can be learnt from the comparison? =. Certainly, housing associations can draw lessons from the examples followed by colleagues within their own countries, but is an international exchange of experiences useful?

The differences between Dutch and English associations do place restrictions on the transferability of best practices. Because the policy freedom and the target group of the Dutch associations is wider, they have more room to look for market opportunities outside the restricted area of housing low-income households. As a consequence the range of options considered in their asset management is broader. English associations are currently less likely to choose sale or substantial renewal if this results in higher, unaffordable rents. Dutch associations have more reasons to consider a larger differentiation in maintenance, allocation and rent policy (as far as regulation allows it). In short, the potential for direct comparisons between the sectors in terms of:

- $\quad$ systems for market-oriented rent policies is low (not to say that both countries cannot learn from each other's rent policies at a national level);

- market-oriented advert models in housing allocation is high and has already taken place;

- $\quad$ market-oriented quality standards is currently low, but might change if rent constraints could be loosened; 
- more dynamic sale and renewal policies is medium. English associations could use sale opportunities to generate additional financial resources for renewals elsewhere. In this respect English associations could consider the introduction of a voluntary 'right to buy', supported by specific sale constraints, as is done by some Dutch associations (see case 2);

- $\quad$ systematic approaches to strategy development is high in respect to the use of general process models (e.g. case 5). More specific structured models (such as in case 3 ) have to be adapted to the national context in respect to the kind of policy options that can be considered. Operational, computerised decisionsupport models for investment planning and financial appraisal may be applicable in both countries.

- comprehensive approaches is high, particularly between the larger housing associations in both countries. Approaches in which objectives are formulated for the performance of the whole housing stock (see case 4) and in which estates are assessed on the basis of their relative position in the housing stock (example 6) are applicable in both countries. However, these approaches will also have to be adapted to the local context in respect to the criteria used and the range of policy options to be considered.

Thus, due to the differences between both housing systems, the transferability of practices has some limitations. Nevertheless, associations in both countries can learn from each others' efforts to systematise the formulation of asset management strategies in a more comprehensive way. With some adaptation to fit the local context, associations could benefit from an exchange of approaches concerning the formulation of goals for the development of the whole housing stock, the categorisation and prioritisation of estates according to predefined asset management strategies and the adoption of targeted sale and shared ownership programmes as part of a wider strategy of market diversification.

\section{References}

Aaker, D.A. (1998) Developing business strategies (fifth edition), New York: John Wiley \& Sons.

Ansoff, H. Igor (1984) Implanting strategic management, New Jersey: Prentice Hall International.

Boelhouwer, P (ed.) (1997) Financing the social rented sector in Western Europe, Housing and Urban Policy Studies, 13, Delft: Delft University Press.

Boor, N., Brugmans, J. and Heeger, H. (2002) Wonen met één, twee of drie sterren [Housing with one, two or three stars], Aedes Magazine, no. 17-18, pp. 40-43.

Broeke, R.A. van den (1998) Strategisch voorraadbeleid van woningcorporaties: informatievoorziening en instrumenten [Strategic housing stock management by housing associations, support-systems and instruments], Delft: Delft University Press.

Brown, T. (2001) Needs and Choice in Social Housing Allocations: A New Research Agenda, Draft Paper to CCHR Conference on 3rd May.

Brown, T., Richardson, J. and Yates, N. (2002) Whose asset management?, Paper presented at the ENHR conference "Housing cultures; convergence and diversity", Vienna. 
Bryson, J. (1995) Strategic planning for public and non-profit organisations, San Francisco: Josey-Bass.

CFV (2001) Verslag financieel toezicht woningcorporaties 2000 [Report financial supervision housing associations 2000], Naarden: Central Housing Fund.

CFV (2002) Het vermogen en de opgave van woningcorporaties: spanning tussen behoefte en middelen [The financial capital and the task of housing associations: tension between need and means], Naarden: Central Housing Fund.

Delftwonen (2002) Strategisch voorraadbeleidsplan [Asset management scheme Delftwonen], Delft.

DETR (2000a) A new financial framework for local authority housing: guidance on business plans, London: DETR.

DETR (2000b), Quality and choice: a decent home for all; the housing green paper, London: DETR.

DETR, (2000c) Collecting, managing and using housing stock information: a good practice guide (3 volumes), London: DETR.

Flier, K. van der and Thomsen, A. (1998) The future of the Dutch housing stock; does the housing stock in the early post-war districts still have a future?, Paper presented at the ENHR conference "Housing Futures: Renewal, Sustainability and Innovation", Cardiff.

Flier, K. van der, and Gruis, V. (2002) Portfolio analysis in social management, European Journal of Housing Policy, 2, pp. 183-202.

Fraser D.L. and Stupak, R.J. (2002) A synthesis of the strategic planning process with the principles of andragogy: learning, leading and linking, International Journal of Public Administration, 25, pp. 1199-1220.

Gruis, V. and Nieboer, N. (2001) What's strategic about housing management? A framework for comparative research, Paper presented at the ENHR-conference "Housing and Urban Development in New Europe", Pułtusk.

Gruis V. and Thomas A. (2002) Approaches to option appraisal in social housing investement; English and Dutch experiences compared, Paper presented at the ENHR conference "Housing cultures; convergence and diversity", Vienna.

Gruis, V., Nieboer, N. and Brown, T. (2003) What determines asset management approaches in the social rented sector, Paper presented at the ENHR conference "Making cities work", Tirana.

Hannagan, T.J. (1992) Marketing for the non-profit sector, London: Macmillan Press.

Heijden, H. van der (2002) Social rented housing in Western Europe: developments and expectations, Urban Studies, 39, pp. 327-340.

Housing Corporation (1999) Good practice guide to maintenance cost forecasting, London: Housing Corporation.

Kemeny, J. (1995) From public housing to the social market; rental policy strategies in comparative perspective, London: Routledge.

Kersloot, J.M. (1999) (Des)investerings- en huurprijsbeleid van verhuurders van woningen [Investment and rent setting policy of landlords], Delft: Delft University Press. Kiddle, C. (2002) Stock rationalisation and the changing structure of English social housing, Paper presented at the ENHR conference "Housing cultures; convergence and diversity", Vienna. 
Kotler, Ph. (1997) Marketing management (ninth edition), New Jersey: Prentice Hall International.

Kullberg, J. (2002) Consumers' responses to choice-based letting mechanisms, Housing Studies, 17, pp. 549-579.

Larkin, A. (2000) Asset Management Strategies; a review of Asset Management Strategies of Housing Associations in England and Social Housing Providers in Australia, London: Metropolitan Housing Trust / The Housing Corporation.

Malpass, P. (2001) The uneven development of 'social rented housing': explaining the historically marginal position of housing associations in Britain, Housing Studies, 16, pp. 225-242.

Marsman, G. and Smit, S. (1999) Feiten en achtergronden huurbeleid verhuurders 1999 [Facts and background rent policy landlords 1999], Amsterdam: RIGO.

Miles, R.E. and Snow, C.C. (1978) Organisational strategy, structure and process, New-York: McGraw Hill.

Mintzberg, H. (1994) The rise and fall of strategic planning, New York: The Free Press.

Mullins, D. (1998) Managing ambiguity: merger activity in the non-profit housing sector, International Journal of Nonprofit and Voluntary Sector Marketing, 4, pp. 349-364. MVROM (2000b), Toezichtsverslag sociale huursector 1999 [Supervision report social rented sector], The Hague: Ministery of VROM.

Newey, M. (2002) Homes vs. life cycle costs; practical lessons in asset management from an English housing association, Paper presented at the ENHR conference "Housing cultures; convergence and diversity", Vienna.

Nieboer N. and Gruis V. (2001) A model for strategic stock management in social housing, Paper presented at the ENHR-conference "Housing and Urban Development in New Europe", Pułtusk.

Nieboer N. and Gruis, V. (2002) What's strategic in the asset management of Dutch landlords, Paper presented at the ENHR conference "Housing cultures; convergence and diversity", Vienna.

Nieboer N.E.T. (2003) Strategisch beslissen over het woningbezit [Strategic decisionmaking on the residential portfolio], Delft: Delft University Press.

NFHA (1994) Stock condition surveys: a basic guide for housing associations, London: National Federation of Housing Associations.

NHF (1997) Reinvestment strategies: a good practice guide, London: National Housing Federation.

Pollit, C. Birchall, J. and Putman, K. (1998) Decentralising public service management, Basingstoke: Macmillan.

Priemus, H. (1996) Recent changes in the social rented sector in the Netherlands, Urban Studies, 33, pp. 1891-1908.

Priemus, H. (2001) Social Housing as a transitional tenure? Reflections on the Netherlands' new housing memorandum 2000-2010, Housing Studies, 16, pp. 243-256.

Priemus, H. (2003) Social housing management: concerns about the effectiveness and efficiency in the Netherlands, Journal of Housing and the Built Environment, 18, pp. 269-279. 
Priemus, H., Dieleman, F. and Clapham, D. (1999) Current developments in social housing management, Netherlands Journal of Housing and the Built Environment, 14, pp. 211-224.

Primavera, A.F. and Wijgert, G.R. van de (2002) Onderzoek naar ICT bij woningcorporaties [Research on ICT at housing associations], Aedes Magazine, no. 4, pp. 34-37.

Riseborough, M. (1997) Private bodies working in public interest? Housing associations presenting images of self, in: D. Mullins and Riseborough, M. (eds.) Changing with the times; critical interpretations of the repositioning of housing associations, Occasional Paper 12, Birmingham, School of Public Policy, University of Birmingham.

Scherpenisse, R. and Vos, M. (2000) Keuzevrijheid als leidraad voor wonen [Freedom of choice as leading principle for housing], Aedes Magazine, no.15, pp. 10-13.

Pearl, M. (1997) Social housing management; a critical appraisal of housing practice, London: Macmillan Press.

Scott, S. , Currie, H., Fitzpatrick, S., Pawson, H., Kintrea, K., Rosengard, A., and Tate, J. (2000) Good practice in housing management: a review of the literature, Edinburgh: The Scottish Exetutive Central Research Unit.

Smans, C. (2002) Rigide scheiding tussen huren en kopen ten einde [Rigid distinction between rent and sale at an end], Aedes Magazine, no.12, pp. 44-47.

Straub, A. (2002) Strategic technical management of housing stock: lessons from Dutch housing associations, Building Research \& Information, 30, pp. 372-381.

Thomsen, A. and van der Flier, K. (2002) Updating the housing stock; the need for renovation-based approaches, Paper presented at the ENHR conference "Housing cultures; convergence and diversity", Vienna.

Walker, R.M. (2001) How to abolish public housing; implications and lessons from public management reform, Housing Studies, 16, pp. 675-696.

Walker, R.M. and Smith, R.S.G. (1999) Regulatory and organisational responses to restructured housing associations finance in England and Wales, Urban Studies, 36, pp. 737-754.

Walker, R.M. and Zon, F. van der (2000) Measuring the performance of social housing organisations in England and the Netherlands: a policy review and research agenda, Journal of Housing and the Built Environment, 15, pp. 183-194.

Wassenberg. F. and Haars, A. (2002) De voortgang van de herstructurering [The progress of urban restructuring], Tijdschrift voor de Volkshuisvesting, no. 5, pp. 37-42.

William Sutton Trust (2000) Stock investment and social change; a case study for a registered social landlord, Tring (Herts, UK): William Sutton Trust. 